\title{
Comparative Research on the International Competitiveness of China's Manufacturing Industry From the Perspective of Global Value Chains Based on World Input-Output Database From 2000 to 2014
}

\author{
Suping Zhao ${ }^{1, *}$ \\ ${ }^{1}$ International Business School, Sichuan International Studies University, Chongqing 400031, China \\ *Corresponding author. Email: 382821096@qq.com
}

\begin{abstract}
Against the background of the development of global production network, the scientific evaluation of national industrial competitiveness needs to consider the global value chain characteristics of export commodities. Based on the revealed comparative advantage index of trade added value adjustment, this paper measures the international competitiveness of 18 sectors of China's manufacturing industry in the 2000-2014, and compares with the world's major economies. It finds that: China's labor-intensive manufacturing industry is not "big but not strong" and remains an important pillar of China's participation in international competition, but facing the fierce challenges of emerging economies, there is a downward trend in international rankings. The various sectors of capital-intensive manufacturing are not in the same level in terms of international competitive strength, development speed and international rankings, but the whole is becoming the main direction of the transformation and upgrading of China's manufacturing industry at present stage. The international competitiveness of the knowledge and technology-intensive sector is poor, except for the computer and optoelectronics industries, there are great differences with advanced economies, but it is gratifying that the international competitiveness of most sectors is showing a rising trend. Therefore, China's manufacturing industry participation in the international division of Labor still needs to rely on laborintensive industries, and continuously tamp the global competitiveness of capital-intensive sectors, cultivate knowledge and technology-intensive manufacturing competitiveness, in order to achieve the overall upgrading of China's manufacturing international competitiveness and gorgeous transformation.
\end{abstract}

Keywords: global value chains, revealed comparative advantage, international competitiveness

\section{INTRODUCTION}

Improving the export competitiveness of China's manufacturing industry is the only way for China to move from a big trading country to a powerful trading

*Fund: The Humanities and Social Science Planning Project of the Ministry of Education - Research on the Identification and Promotion of China's Manufacturing Export Competitiveness from the Perspective of Global Value Chain (16YJC790146); Social Science Project of Chongqing - Research on Trade Facilitation Innovation and Economic Development Synergy of Chongqing Free Trade Area (2017QNJJ12); International Humanities Construction of Clooeges and Universities in Chongqing - Research on the Export Competitiveness of Chinese Industrial Products in the Context of the "Belt and Road" (Non-Common Language) (CIISFTGB 1907); University-level project of Sichuan International Studies University - Analysis on the Industrial Heterogeneity of Value-added Rate and Its Threshold Effect" (SISU201523).

CLCN: F740.2 country. It is the proper meaning of implementing "Made in China 2025 strategy", and also an effective way to cope with the global economic slowdown, especially the weak overseas market demand. Since the 1990s, China's manufacturing industry has been deeply integrated into the world's production system, and China gradually becomes the largest producer and exporter. Many export products also reflect high technology level and international competitiveness, such as Apple mobile phones. This has aroused strong repercussions from the international community on the export strength of China's manufacturing industry. Based on the research of customs trade data, some scholars believe that the technical complexity of China's manufacturing exports has reached the level of other countries whose per capita GDP are three times of China (Hausmann et al., 2007) [1]. China has entered 
the ranks of developed economies (Lemoine and unal, 2008) [2], and is still rapidly improving (Schott, 2008) [3]. At the same time, some scholars believe that China participates in the global value chain led by multinational companies with the advantage of labor factor endowment. Although the final product is formed in China, its key technology and main added value are still controlled and acquired by foreign capital (Fuest C, 2008 [4]; Johnson and Noguear, 2012 [5]; Theodore H. Moran, 2011 [6]). In the long run, China's manufacturing industry may fall into the "comparative advantage trap", and then be locked at the low end of the value chain, which is not conducive to transformation and upgrading and high-quality development.

This paper holds that the development of China's manufacturing industries and foreign trade pattern have typical feature of "putting both ends of the production process (the supply of raw materials and the marketing of products) on the world market". A large number of foreign intermediate products, advanced technology and service elements are invested in the production process of products. Therefore, when ignoring the differences in technology level and added value of different production links, and attributing all the technical level and value contribution of the whole product to China, it is likely to miscalculate the real competitiveness level of China's manufacturing export products. Therefore, in the context of the global production network, it is necessary to re-understand the world trade pattern with the added value as the statistical caliber, and then identify the international competitiveness level and structural characteristics of all sectors of China's manufacturing industry. On this basis, it is required to find the influencing factors of export competitiveness and the way to improve, so as to improve the pertinence and effectiveness of policy recommendations. In view of this, this paper will use the World Input-output Database (WOID) to measure the export value added by manufacturing industries of major world economies in 2000-2014. On this basis, the trade added value is introduced into the RCA (revealed comparative advantage) index to calculate and analyze the real competitive advantage, evolution trend and division of labor status of all sectors of China's manufacturing industry.

\section{LITERATURE REVIEW}

International competitiveness has always been an important research topic in the field of international economics, which has been widely concerned by scholars, and its measurement methods have been evolving towards diversification. Firstly, viewing from the micro perspective of enterprises and products, under the assumption of product homogeneity, the domestic productivity usually determines the international competitiveness of enterprises (Krugman, 1994) [7].
When considering the heterogeneity of different brands or models in the same kind of goods, the export price is often used as the indicator of product quality and international competitiveness (Hu Zhaoling and Song Jia, 2013) [8]. For example, Apple mobile phone has higher price, better quality and greater market share compared with other brands. However, the productivity indicator ignores the impact of international division of labor and cost inputs. In fact, the division of labor position and export profits on the "smiling curve" can also reflect the competitive strength of different suppliers of notebook computer parts (Xu Meina and Shen Yuliang, 2011) [9].

Compared with the case analysis from the micro perspective, scholars prefer to measure and study the competitiveness of industries and countries at the macro level, which also spawns many new measurement methods. International market share has become the first index to be used. However, due to neglecting the size of national economic aggregate and export scale, it is quickly replaced by competitiveness index (TC, the proportion of trade balance and total trade of a certain industry in a country). In essence, this index is still an extension of mercantilism. In order to describe the relative influence of the export scale of a certain industry in the world, Balassa (1965) [10] proposed the RCA index (the ratio of the share of a certain product in a country's total export to the share of that product in the world's total export) to measure the international competitiveness of this industry, which has been widely used. Lall et al. (2006) [11], Hausmann et al. (2007) [1] put forward the technology complexity index of export product (SI) and the national export productivity index (EXPY). However, the index is doubted because it assumes that the technology level of the same kind of products in different countries is closely related to the national per capita income, especially in the context of the further development of the international production network, developing economies can gain strong international competitiveness in certain products by virtue of their advantages in division of labor, which contradicts the above hypothesis. The measurement result of this index may underestimate the competitive strength of developing countries. Therefore, in this paper, it is believed that RCA index can reflect the international competitiveness level and its changing trend of the industry by considering the influence of the export scale of a country and the total export volume of the world (Jin Bei et al., 2013 [12]; Fu Jingyan and Li Lisha, 2010 [13]).

However, the application of RCA index is also limited by the global production network. When calculating RCA based on the total export value of customs, the division of domestic and foreign production in the industrial sector is ignored, and the circular effect of industrial value among countries and industries is not considered, which may lead to biased 
results. Therefore, it is necessary to first identify the level of trade gains in the context of international division of production (Ge Ming and Zhao Suping, 2017) [14]. With the development of global value chain theory, the identification technology of trade value added has been constantly enriched. The pioneering contribution comes from the vertical specialization index (including forward and backward vertical specialization index) proposed by Hummels et al. (2001) [15]. In subsequent research, this idea has been developed. Based on the single regional input-output model (Daudin et al., 2011 [16]; Koopman et al., 2010 [17]; Hong Ma et al., 2015 [18]), the composition of global value chain of international trade can be decomposed. According to the world input-output framework (Johnson and Noguear, 2012 [5]; Stehrer, 2012 [19]; Timmer, 2014 [20]; Li Xin and Xu Dianqing, 2013 [21]), the source and final destination of export value of each industry in a country are clarified. Wang et al. (2013) [22] divided the export volume into 16 parts according to value sources and different final absorption places, and completed the total decomposition of the value added of export trade, laying a methodological foundation for the study of international competitiveness of manufacturing industry from the perspective of global value chain.

Wang Zhi et al. (2015) [23] introduced the concept of trade value added into the traditional RCA index, and proposed the RCA accounting model from the perspective of global value chain, but did not study the actual international competitiveness level of China's manufacturing industry. Zeng (2017) [24] compared the industrial competitiveness and current account sustainability of China and the United States from the perspective of trade value added, which did not reflect

$$
\left(\begin{array}{c}
x_{1} \\
x_{2} \\
\vdots \\
x_{m}
\end{array}\right)=\left(\begin{array}{cccc}
A_{11} & A_{12} & \cdots & A_{1 m} \\
A_{21} & A_{22} & \cdots & A_{2 m} \\
\vdots & \vdots & \ddots & \vdots \\
A_{m 1} & A_{m 2} & \cdots & A_{m m}
\end{array}\right)\left(\begin{array}{c}
x_{1} \\
x_{2} \\
\vdots \\
x_{m}
\end{array}\right)+\left(\begin{array}{cccc}
f_{11} & f_{12} & \cdots & f_{1 m} \\
f_{21} & f_{22} & \cdots & f_{2 m} \\
\vdots & \vdots & \ddots & \vdots \\
f_{m 1} & f_{m 2} & \cdots & f_{m m}
\end{array}\right)=\left(\begin{array}{cccc}
L_{11} & L_{12} & \cdots & L_{1 m} \\
L_{21} & L_{22} & \cdots & L_{2 m} \\
\vdots & \vdots & \ddots & \vdots \\
L_{m 1} & L_{m 2} & \cdots & L_{m m}
\end{array}\right)\left(\begin{array}{c}
f_{1^{*}} \\
f_{2^{*}} \\
\vdots \\
f_{m^{*}}
\end{array}\right)_{(1}
$$

The form of application block matrix can be abbreviated as:

$$
x=A x+f=(I-A)^{-1} f=L f
$$

In the above formula, $x=\left(x_{1}^{\prime}, x_{2}{ }^{\prime}, \cdots, x_{m}{ }^{\prime}\right)^{\prime}$ is the total output column vector of the world (dimension $m n \times 1), x_{r}$ represents the total output vector of $r$ (dimension $n \times 1$ ), and $x_{r}^{\prime}$ represents the transpose of vector (matrix) ${ }^{x_{r}}$. Matrix $A$ (dimension $m n \times m n$ ) represents the global production network, and the position of China's manufacturing industry in the division of labor in the world. Dai Xiang (2015) [25], Yuan Honglin, etc. (2017) [26] compared the competitiveness level of China's manufacturing sector in 1995-2011 under the accounting standards of gross value and value added. However, it is still doubtful whether the conclusion can reflect the characteristics of the current international competitiveness of the manufacturing industry.

To sum up, this paper will use decomposition model of export value added by Koopman et al. (2014) [27] and newly designed RCA index by Wang Zhi et al. (2015) [23] to study and analyze the level structure, evolution characteristics and international status of international competitiveness of all sectors of China's manufacturing industry in 2000-2014 by using the 2016 version of World Input-output Database.

\section{RESEARCH METHODS}

This part first introduces the MRIO (multi-regional input-output) analysis framework. On this basis, it decomposes the composition of global value chain of the export trade volume of various industries in various countries, then explains the new RCA concept and model, and finally introduces the measurement model of the international competitiveness of various sectors of manufacturing industry.

\section{A. MRIO framework}

Assuming that there are $m$ countries or regions in the world, and each country has $n$ production sectors (industries), the MRIO model composed can be expressed as:

submatrix $A_{r r}$ on the diagonal (dimension $n \times n$ ) describes direct consumption coefficient of domestic various industries of $r$. The submatrix $A_{r s}$ outside the diagonal (dimension $n \times n$ ) represents intermediate input coefficient of all departments of $r$ in the process of production needed by the various departments of $S$, depicting the degree of direct mutual demand between the production sectors of different countries. And $A_{r s} x_{s}$ reflects the intermediate goods exports of $r$ for $s$. $L=(I-A)^{-1}$ is Leontief inverse matrix, and $I$ is unit matrix. $f_{r r}$ represents self-produced and self- 
marketed final demand product of $r$, and $f_{r s}(r \neq s)$ is final product produced by $r$ but consumed by $S$, that is, the final product export of $r$ for $s$. $f_{r^{*}}=\sum_{s=1}^{m} f_{r s}$ represents final product column vector of $r$, and $f=\left(f_{1^{*}}{ }^{\prime}, f_{2^{*}}{ }^{\prime}, \cdots, f_{\mathrm{m}^{*}}{ }^{\prime}\right)^{\prime}$ is the final output column vector of various countries in the world.

\section{B. GVC decomposition of value of export}

$V=\left(\begin{array}{llll}V_{1} & V_{2} & \cdots & V_{m}\end{array}\right)$ represents the row vectors of the value added of each country (dimension $1 \times m n)$, and the row vector of value added rate of a country is $v=\left(\begin{array}{llll}v_{1} & v_{2} & \cdots & v_{m}\end{array}\right)$. In $v_{r}=V_{r} / X_{r}^{\prime}=\mu\left(I-\sum_{s} A_{s r}\right), \mu$ is a row vector with all factors being 1 , and $\hat{v}$ represents the diagonal matrix of row vector $v$. $E=\left(\begin{array}{llll}E_{1} & E_{2} & \cdots & E_{m}\end{array}\right)_{\text {represents the row vector }}$ of general export of each country (dimension $1 \times m n$ ), and $E_{r \text { (dimension }} 1 \times n$ ) is the export row vector of $n$ industry of $r$ country. $\hat{E}_{\text {is }}$ the diagonal matrix of row vector $E$. Then, the matrix $G V C$ (dimension $m n \times m n$ ) formed by the total exports of each country's industries can be expressed as:

$$
G V C=\hat{v}(I-A)^{-1} \hat{E}=\hat{v} L \hat{E}=\left(\begin{array}{cccc}
\hat{v}_{1} L_{11} \hat{E}_{1} & \hat{v}_{1} L_{12} \hat{E}_{2} & \cdots & \hat{v}_{1} L_{1 m} \hat{E}_{m} \\
\hat{v}_{2} L_{21} \hat{E}_{1} & \hat{v}_{2} L_{22} \hat{E}_{2} & \cdots & \hat{v}_{2} L_{2 m} \hat{E}_{m} \\
\cdots & \cdots & \ddots & \cdots \\
\hat{v}_{m} L_{m 1} \hat{E}_{1} & \hat{v}_{m} L_{m 2} \hat{E}_{2} & \cdots & \hat{v}_{m} L_{m m} \hat{E}_{m}
\end{array}\right)
$$

In the above matrix, the matrix $\hat{v}_{r} L_{r r} \hat{E}_{r}$ in $r$ line on the diagonal indicates that the domestic value added contained in the total exports $E_{r}$ of each industry of $r$ country is $V A E_{r}$ (dimension $n \times n$ ). In matrix $V A E_{r}$, line $i$ shows the vector $V A E_{r}^{i}$ (dimension $1 \times n$ ) of domestic export value added of $i$ industry in $r$ country. The sum of factors of the vector is the export value added vector $v a e_{r}^{i}$ (dimension $1 \times 1$ ) of $i$ industry in $r$ country. In addition, the sum of non-diagonal matrix factors in line $r$ of $G V C$ is $F V_{r}=\sum_{s \neq r} v_{s} L_{s r} E_{r^{*}}$, the sum of value added of other countries included in the exports of $r$ country. In $v_{r} L_{r r}+\sum_{s \neq r} v_{s} L_{s r}=v L_{* r}=\mu$,
$L^{{ }^{*} r}$ represents the vectors in line $r$ of matrix $L$, and $\mu$ is a row vector with all factors being 1 . Therefore, $D V_{r}+F V_{r}=E_{r^{*}}$ can be obtained. The sum of nondiagonal matrix factors in line $r$ of $G V C$ is the value added of $r$ country included in the export trade between $s$ country and $t$ country, namely, $I V_{r}=v_{r} \sum_{s \neq t, r} L_{r s} E_{s t}$.

\section{RCA index}

Considering the domestic and foreign division of labor and its value contribution in the production process of export commodities, this paper uses the newly constructed indicator $R C A_{-} G V C_{i}^{r}$ by Wang Zhi et al. (2015) for reference to measure the international competitiveness of $i$ manufacturing industry of $r$ country. The basic idea is that the proportion of the domestic value added of China's exports in the total domestic value added of exports relative to the world average level, which can reflect the international competitiveness of this industry.

$$
R C A_{-} G V C_{r}^{i}=\frac{v a e_{r}^{i} / \sum_{i}^{n}\left(v a e_{r}^{i}\right)}{\sum_{r}^{G}\left(v a e_{r}^{i}\right) / \sum_{r}^{G} \sum_{i}^{n}\left(v a e_{r}^{i}\right)}
$$

In the matrix, $r$ represents the country, $G$ represents all the countries in the world, $i$ represents the industrial sectors, $n$ represents all the industries, vae refers to the domestic value added. According to the standard put forward by JERTO, $R C A_{-} G V C_{r}^{i}>2.5$ indicates that $i$ industry of $r$ country has strong competitiveness; $1.25 \leqq$ $R C A_{-} G V C_{r}^{i} \leqq 2.5$ shows that $i_{\text {industry of }} r$ country has strong international competitiveness; $0.8 \leqq$ $R C A_{-} G V C_{r}^{i} \leqq 1.25$ shows that $i$ industry of $r$ country has moderate international competitiveness; and $R C A_{-} G V C_{r}^{i}<0.8$ shows that $i$ industry of $r$ country has weak competitiveness.

\section{Data source}

The data in this paper are from the world inputoutput database (WIOD), 2016. The database contains input-output data of 56 industrial sectors in 44 economies (see "Table I" for details) in 2000-2014, including 18 manufacturing sectors, code C5-C22. According to the classification method of Ge Ming and Lin Ling (2016) [28], it is divided into three major categories: labor-intensive manufacturing industry, capital-intensive manufacturing and knowledge and 
technology-intensive manufacturing according to

II" for the details). different factor endowment characteristics (see "Table

TABLE I. CHINESE NAMES AND ENGLISH ABBREVIATIONS OF 44 ECONOMIES IN WORLD INPUT-OUTPUT TABLE

\begin{tabular}{|c|c|c|c|c|c|c|c|c|c|c|c|}
\hline $\begin{array}{c}\text { Serial } \\
\text { Number }\end{array}$ & \begin{tabular}{|c|} 
English \\
abbreviation
\end{tabular} & $\begin{array}{c}\text { Chinese } \\
\text { name }\end{array}$ & \begin{tabular}{|c|} 
Serial \\
Number
\end{tabular} & \begin{tabular}{|c|} 
English \\
abbreviation
\end{tabular} & $\begin{array}{c}\text { Chinese } \\
\text { name }\end{array}$ & $\begin{array}{c}\text { Serial } \\
\text { Number }\end{array}$ & \begin{tabular}{c|} 
English \\
abbreviation
\end{tabular} & $\begin{array}{c}\text { Chinese } \\
\text { name }\end{array}$ & \begin{tabular}{|c|} 
Serial \\
Number
\end{tabular} & $\begin{array}{c}\text { English } \\
\text { abbreviation }\end{array}$ & $\begin{array}{c}\text { Chinese } \\
\text { name }\end{array}$ \\
\hline 1 & AUS & 澳大利亚 & 12 & DNK & 丹麦 & 23 & IRL & 爱尔兰 & 34 & POL & 波兰 \\
\hline 2 & AUT & 奥地利 & 13 & ESP & 西班牙 & 24 & ITA & 意大利 & 35 & PRT & 葡萄牙 \\
\hline 3 & BEL & 比利时 & 14 & EST & 爱沙尼亚 & 25 & JPN & 日本 & 36 & $\mathrm{ROU}$ & 罗马尼亚 \\
\hline 4 & BGR & 保加利亚 & 15 & FIN & 芬兰 & 26 & KOR & 韩国 & 37 & RUS & 俄罗斯 \\
\hline 5 & BRA & 巴西 & 16 & FRA & 法国 & 27 & LTU & 立陶宛 & 38 & SVK & 斯洛伐克 \\
\hline 6 & CAN & 加拿大 & 17 & GBR & 英国 & 28 & LUX & 卢森堡 & 39 & SVN & 斯洛文尼亚 \\
\hline 7 & $\mathrm{CHE}$ & 瑞士 & 18 & GRC & 希腊 & 29 & LVA & 拉脱维亚 & 40 & SWE & 瑞典 \\
\hline 8 & $\mathrm{CHN}$ & 中国 & 19 & HRV & 克罗地亚 & 30 & MEX & 墨西哥 & 41 & TUR & 土耳其 \\
\hline 9 & CYP & 塞浦路斯 & 20 & HUN & 匈牙利 & 31 & MLT & 马耳他 & 42 & TWN & 中国台湾 \\
\hline 10 & CZE & 捷克 & 21 & IDN & 印度尼西亚 & 32 & NLD & 荷兰 & 43 & USA & 美国 \\
\hline 11 & $\mathrm{DEU}$ & 德国 & 22 & IND & 印度 & 33 & NOR & 挪威 & 44 & ROW & 其它 \\
\hline
\end{tabular}

\section{RESEARCH RESULTS}

This part will analyze the $R C A_{-} G V C$ index of each sector of China's manufacturing industry from three aspects: level characteristics, evolution trend and international status, so as to understand the international competitiveness of China's manufacturing industry in a more comprehensive way.

\section{A. International competitiveness of all sectors of China's manufacturing industry in 2014}

In "Table II", it shows the international competitiveness index of 18 sectors of three factor endowment structure of China's manufacturing industry in 2014 from the perspective of global value chain. From the measurement results, it finds the following characteristics. First, very few sectors show strong international competitiveness, such as textile and clothing manufacturing industry (C06), with RCA_GVC index as high as 2.76, showing that China's comparative advantage is still focused on laborintensive sectors. With the development of domestic market, the improvement of people's demand, the development of industrial cluster, the improvement of technology and capital strength, China's labor-intensive manufacturing sector is not only large-scale but also competitive. Secondly, many sectors have strong international competitiveness and diversified factor density distribution. Eight manufacturing sectors have strong international competitiveness, such as timber and woodware industry (C07), other non-metallic mineral product manufacturing (C14), computer, electronic product and optical product manufacturing (C17), power equipment manufacturing (C18), basic metal manufacturing (C15), furniture manufacturing and other manufacturing industries (C22), rubber and plastics products (C13) and printing and publication (C09). Among them, there are two labor-intensive sectors, highlighting that China's competitive advantage depends on labor-intensive factor endowment. There are two knowledge and technology-intensive sectors, which are mainly due to China's strong domestic demand, extensive investment, market competition and innovation of enterprise, accelerate the development of photovoltaic products and power equipment, and obtain international competitiveness in knowledge-intensive manufacturing. There are also 4 capital-intensive sectors. In recent years, China has accumulated more capital due to its rapid economic development, and the factor endowment structure has also changed significantly, which is mainly characterized by a substantial increase in per capital stock. Therefore, it also strongly promotes the development of capitalintensive industries. Thirdly, the remaining three industries in the capital-intensive manufacturing industry, such as food and beverage, tobacco industry (C05), paper industry ( $\mathrm{C} 08)$, coke refined petroleum industry (C10), all belong to the industries with medium international competitiveness. In addition, there are also three knowledge and technologyintensive industries, including chemical manufacturing (C11), unclassified machinery and equipment manufacturing (C19), other metal product manufacturing (C16), etc., showing the adjustment of China's factor endowment structure. However, the development of various industries is not balanced. The main reason lies in the fact that China's capitalintensive sectors and knowledge and technologyintensive sectors still participate in the international division of labor with processing and manufacturing as the main mode, resulting in their lack of dominance in the global value chain, and they need to rely heavily on 
changes in the external market environment. Fourth, industries with weak international competitiveness are concentrated in knowledge and technology intensive sectors, such as pharmaceutical manufacturing (C12), automobile manufacturing (C20), and other transportation equipment manufacturing (C21). These industries have a broad market and development space in China, but they still belong to the category of infant industries at this stage. Therefore, their development needs to follow the market mechanism. At the same time, it also needs certain policy tilt and protection.

TABLE II. RCA_GVC INDEX OF INTERNATIONAL COMPETITIVENESS OF VARIOUS SECTORS OF CHINA'S MANUFACTURING INDUSTRY IN 2014

\begin{tabular}{|c|c|c|c|}
\hline Factor endowment characteristics & $\begin{array}{c}\text { Unit serial } \\
\text { number }\end{array}$ & Manufacturing sector & RCA_GVC \\
\hline \multirow{3}{*}{$\begin{array}{l}\text { Labor-intensive } \\
\text { industry }\end{array}$} & $\mathrm{C} 06$ & textile and clothing manufacturing industry & 2.76 \\
\hline & $\mathrm{C} 07$ & timber and woodware industry & 2.02 \\
\hline & $\mathrm{C} 22$ & furniture manufacturing and other manufacturing industries & 1.49 \\
\hline \multirow{7}{*}{ Capital-intensive manufacturing } & $\mathrm{C} 05$ & food and beverage, tobacco industry & 1.07 \\
\hline & $\mathrm{C} 08$ & paper-making industry & 1.01 \\
\hline & $\mathrm{C} 09$ & printing and publishing & 1.28 \\
\hline & $\mathrm{C} 10$ & coke refined petroleum & 0.98 \\
\hline & $\mathrm{C} 13$ & rubber and plastics products & 1.3 \\
\hline & $\mathrm{C} 14$ & other non-metallic mineral product manufacturing & 1.87 \\
\hline & $\mathrm{C} 15$ & basic metal manufacturing & 1.51 \\
\hline \multirow{8}{*}{$\begin{array}{l}\text { Knowledge and technology- } \\
\text { intensive manufacturing }\end{array}$} & C11 & chemical manufacturing & 1.15 \\
\hline & $\mathrm{C} 12$ & pharmaceutical manufacturing & 0.32 \\
\hline & $\mathrm{C} 16$ & other metal product manufacturing & 0.91 \\
\hline & $\mathrm{C} 17$ & computer, electronic product and optical product manufacturing & 1.84 \\
\hline & C18 & power equipment manufacturing & 1.8 \\
\hline & C19 & unclassified machinery and equipment manufacturing & 1.15 \\
\hline & $\mathrm{C} 20$ & automobile manufacturing & 0.55 \\
\hline & $\mathrm{C} 21$ & other transportation equipment manufacturing & 0.69 \\
\hline
\end{tabular}

\section{B. Evolution trend of international competitiveness of China's manufacturing industry}

According to the time series characteristics of the international competitiveness of all sectors of manufacturing industry, this paper divides the evolution trend into five aspects.

1) Significant improvement in international competitiveness: The competitiveness of six industry sectors, such as $\mathrm{C} 07$ and $\mathrm{C} 16-20$, has been significantly improved during the sample period. It should be emphasized that except for $\mathrm{C} 07$, which belongs to labor-intensive industry, the other five belong to knowledge and technology-intensive sectors, highlighting the changes in the factor endowment structure and the development direction of international competitiveness in the future. At the same time, it shows that with the increasing competitive pressure brought by market opening, knowledge-intensive sectors strive to climb the high end of the global value chain, and change the unfavorable position of benefit distribution through transformation and upgrading.

2) Significant decline in international competitiveness: The international competitiveness of 2 labor-intensive sectors such as C6 and C22 and 2 capital-intensive sectors such as $\mathrm{C} 10$ and $\mathrm{C} 13$ showed a significant decline in international competitiveness during the sample period. On the one hand, it reflects that China's factor endowment structure is moving towards the direction of upgrading, while the laborintensive sectors with comparative advantages are facing fierce competition of labor cost advantages of emerging economies. On the other hand, some capitalintensive products, such as coke refined petroleum, rubber and plastic products, and other consumables and intermediate inputs, show a continuous decline in international competitiveness due to the domestic economic development, accelerated investment and consumption growth, which focus on imports from abroad rather than exports.

3) The international competitiveness remains stable: The RCA_GVC index of food and beverage, tobacco industry (C05), paper industry (C08) and pharmaceutical manufacturing (C12) basically have not changed in the sample period. The three industries share one common feature, that is, the demand elasticity and supply elasticity are relatively low, so the import and export changes are not large. However, it should be noted that pharmaceutical manufacturing industry is related to the realization of healthy China. Therefore, it is necessary to increase R\&D efforts and technical level to improve supply capacity, quality and efficiency.

4) The international competitiveness shows a " $V$ shaped" change: The printing and publication (C09) and other non-metallic mineral product manufacturing (C14) all belong to capital-intensive sectors. However, the lowest point of the international competitiveness of 
C09 occurred in the period of the U.S. financial crisis in 2008, reflecting the serious dependence of C09 on the U.S. market and the significant impact of the financial crisis on China's capital market. The lowest point of international competitiveness of $\mathrm{C} 14$ appeared at the beginning of China's accession to the WTO in 2002. With the improvement of the opening level, the competitiveness of other domestic non-metallic mineral products has also been rapidly improved, which to a certain extent reflects that the open economy and market competition can effectively stimulate the competitiveness of domestic industries.

5) The international competitiveness shows "inverted V-shaped changes": Three sectors, i.e. chemical manufacturing (C11), basic metal manufacturing (C15) and other transportation equipment manufacturing (C21) have shown "inverted V-shaped changes" in the international competitiveness. The highest level of international competitiveness appeared in 2008, highlighting the negative impact brought by the slow development of the world economy and sluggish external demand in recent years, and also reflecting that although China is a big manufacturing country and export country of $\mathrm{C} 15$, the international competitiveness is not high. With the continuous decline of international competitiveness of knowledge and technology-intensive sectors, such as C11 and C21, it is necessary to encourage innovation-driven development and strengthen intellectual property protection.

TABLE III. EVOLUTION OF INTERNATIONAL COMPETITIVENESS OF CHINA'S MANUFACTURING SECTORS IN 2000-2014

\begin{tabular}{|c|c|c|c|c|c|c|c|c|c|c|c|}
\hline Sector & 2000 & 2002 & 2004 & 2006 & 2008 & 2010 & 2011 & 2012 & 2013 & 2014 & $\begin{array}{l}\text { Mean } \\
\text { value }\end{array}$ \\
\hline C06 & 3.46 & 2.98 & 3.16 & 3.32 & 3.23 & 3.14 & 3.1 & 3.03 & 2.92 & 2.76 & 3.15 \\
\hline $\mathrm{C} 07$ & 1.42 & 1.44 & 1.67 & 1.87 & 1.92 & 1.81 & 1.98 & 2.14 & 2.13 & 2.02 & 1.81 \\
\hline $\mathrm{C} 22$ & 2.27 & 1.93 & 1.56 & 2.13 & 1.79 & 1.27 & 1.33 & 1.6 & 1.54 & 1.49 & 1.78 \\
\hline $\mathrm{C} 05$ & 1.15 & 0.98 & 1.04 & 1.13 & 1.11 & 1.09 & 1.11 & 1.16 & 1.11 & 1.07 & 1.08 \\
\hline $\mathrm{C} 08$ & 0.86 & 1.02 & 1 & 0.97 & 1 & 0.97 & 1.04 & 1.09 & 1.03 & 1.01 & 0.99 \\
\hline $\mathrm{C} 09$ & 1.43 & 1.62 & 1.27 & 1.04 & 0.99 & 1.12 & 1.18 & 1.31 & 1.32 & 1.28 & 1.25 \\
\hline $\mathrm{C} 10$ & 1.19 & 1.16 & 1.08 & 1 & 1.03 & 1.34 & 1.05 & 0.97 & 0.99 & 0.98 & 1.08 \\
\hline $\mathrm{C} 13$ & 1.56 & 1.67 & 1.58 & 1.5 & 1.43 & 1.33 & 1.36 & 1.37 & 1.36 & 1.3 & 1.47 \\
\hline $\mathrm{C} 14$ & 1.8 & 1.38 & 1.38 & 1.52 & 1.58 & 1.69 & 1.84 & 1.94 & 2.01 & 1.87 & 1.64 \\
\hline $\mathrm{C} 15$ & 1.37 & 1.6 & 1.9 & 1.8 & 1.96 & 1.71 & 1.7 & 1.59 & 1.51 & 1.51 & 1.69 \\
\hline C11 & 1.18 & 1.15 & 1.2 & 1.31 & 1.43 & 1.2 & 1.29 & 1.21 & 1.17 & 1.15 & 1.24 \\
\hline $\mathrm{C} 12$ & 0.33 & 0.27 & 0.3 & 0.31 & 0.35 & 0.32 & 0.31 & 0.33 & 0.34 & 0.32 & 0.31 \\
\hline $\mathrm{C} 16$ & 0.72 & 0.74 & 0.82 & 0.88 & 0.91 & 0.88 & 0.88 & 0.96 & 0.94 & 0.91 & 0.85 \\
\hline $\mathrm{C} 17$ & 1.06 & 1.35 & 1.78 & 1.82 & 1.79 & 1.91 & 1.88 & 1.9 & 1.89 & 1.84 & 1.69 \\
\hline $\mathrm{C} 18$ & 1.39 & 1.5 & 1.5 & 1.53 & 1.69 & 1.75 & 1.8 & 1.86 & 1.82 & 1.8 & 1.62 \\
\hline $\mathrm{C} 19$ & 0.83 & 0.94 & 1.05 & 1.08 & 1.29 & 1.27 & 1.28 & 1.17 & 1.19 & 1.15 & 1.11 \\
\hline $\mathrm{C} 20$ & 0.25 & 0.28 & 0.29 & 0.32 & 0.44 & 0.57 & 0.57 & 0.53 & 0.56 & 0.55 & 0.41 \\
\hline $\mathrm{C} 21$ & 0.39 & 0.44 & 0.56 & 0.59 & 0.74 & 0.9 & 0.89 & 0.81 & 0.75 & 0.69 & 0.65 \\
\hline $\begin{array}{l}\text { mean } \\
\text { value }\end{array}$ & 1.26 & 1.25 & 1.29 & 1.34 & 1.37 & 1.35 & 1.37 & 1.39 & 1.37 & 1.32 & 1.32 \\
\hline
\end{tabular}

a. Note: due to length limitation, the data of odd years from 2000 to 2010 are not listed in this table. If you are interested in it, please contact the author.

\section{Comparison of the international status of China's manufacturing competitiveness}

The above analysis focuses on the level characteristics and changing trend of the international competitiveness of China's manufacturing sector, which is not enough to explain its international status. For example, according to the calculation formula, the RCA_GVC index of a certain sector in many countries may exceed 2.5. How to analyze the international competitiveness of China's manufacturing sector? This paper further analyzes the international competitiveness of China's manufacturing industry through the horizontal comparison between countries.

It can be seen from "Table IV" that among 43 major economies and 18 manufacturing sectors, 7 industries in China can enter the top 10 of global competitiveness, namely, two labor-intensive industries, such as C06 (ranking 2) ${ }^{1}$, C22 (10), two capital-intensive industries, such as C14 (ranking 6), C15 (ranking 6), three knowledge-intensive industries, such as C11 (ranking

http://www.wiod.org/home 
10), C17 (ranking 4), C18 (ranking 7). Among them, the textile and clothing manufacturing industry (C06) ranks the second. As a typical representative of China's labor-intensive factor endowment, its international competitiveness is second only to Turkey, which is the main OEM country of European and American clothing brands, and its textile and clothing industry is also very developed. The computer, electronic product and optical product manufacturing (C17) ranks the fourth, second only to Taiwan, South Korea and Japan, which is closely related to the position of international division of labor and the way of participation. At present, the links with high added value of the industry are still mainly controlled by the above three economies.

China has 7 manufacturing sectors ranking 11-20, which respectively are $\mathrm{C} 07$ (ranking 14, labor-intensive industry), C08 (ranking 20, capital intensive industry), C09 (ranking 14, capital intensive industry), C10 (ranking 16, capital intensive industry), C13 (ranking 16, capital intensive industry), C19 (ranking 12, knowledge-intensive industry), C21 (ranking 16, knowledge-intensive industry). As one of the few developing countries among 43 economies, 14 manufacturing sectors have entered the top 20, indicating that China's overall competitiveness of manufacturing industry is in the forefront of the world, and also in line with the division of labor status of "world factory". The characteristics of 3:6:5 of the three sectors with factor endowment structure also reflect the diversified direction of the competitive advantage of China's manufacturing sector to a certain extent.

At the same time, it can be seen that China still has four manufacturing sectors ranking at the bottom, namely, C05 (ranking 23, capital-intensive manufacturing sector), C12 (ranking 31, knowledgeintensive manufacturing sector), C16 (ranking 27, knowledge-intensive manufacturing sector) and C20 (ranking 24, knowledge-intensive manufacturing sector), showing that China's current competitiveness is still concentrated in labor-intensive sectors, and reflecting the trend of transferring to capital-intensive sectors. Although the knowledge-intensive industries have some outstanding sectors, they still have more competitive pressure on the whole.

TABLE IV. INTERNATIONAL COMPETITIVENESS AND COMPARISON OF CHINA'S MANUFACTURING SECTORS IN 2014

\begin{tabular}{|c|c|c|c|c|c|c|c|c|c|c|c|c|}
\hline \multirow{2}{*}{$\begin{array}{l}\text { Industry } \\
\text { ranking }\end{array}$} & \multicolumn{2}{|c|}{$\mathrm{C} 22$} & \multicolumn{2}{|c|}{ C06 } & \multicolumn{2}{|c|}{$\mathrm{C07}$} & \multirow{2}{*}{$\begin{array}{c}\mathrm{C05} \\
\text { Nation }\end{array}$} & \multicolumn{3}{|c|}{$\mathrm{C08}$} & \multicolumn{2}{|c|}{ C09 } \\
\hline & Nation & $R C A$ & Nation & $R C A$ & Nation & $R C A$ & & $R C A$ & Nation & $R C A$ & Nation & $R C A$ \\
\hline 1 & LTU & 3.22 & TUR & 5.2 & LVA & 10.96 & IRL & 3.91 & FIN & 7.58 & MLT & 4.28 \\
\hline 2 & IRL & 2.64 & $\mathrm{CHN}$ & 2.76 & EST & 10.17 & IDN & 3.33 & SWE & 3.44 & EST & 3.09 \\
\hline 3 & MLT & 2.2 & PRT & 2.63 & LTU & 4.16 & BRA & 2.45 & IDN & 2.51 & $\mathrm{CAN}$ & 2.44 \\
\hline 4 & MEX & 1.67 & ITA & 2.57 & PRT & 3.34 & LTU & 2.11 & PRT & 2.31 & JPN & 2.39 \\
\hline 5 & ITA & 1.66 & IDN & 2.31 & SVN & 3.33 & ESP & 2 & AUT & 2.1 & SVN & 2.08 \\
\hline 6 & IND & 1.65 & IND & 1.74 & ROU & 3.26 & LVA & 1.93 & BRA & 2.06 & ESP & 1.99 \\
\hline 7 & EST & 1.58 & ROU & 1.65 & FIN & 2.82 & BEL & 1.91 & POL & 1.74 & AUT & 1.94 \\
\hline 8 & BRA & 1.55 & BGR & 1.63 & SVK & 2.71 & HRV & 1.85 & SVN & 1.66 & HRV & 1.89 \\
\hline 9 & TUR & 1.55 & LTU & 1.56 & IDN & 2.65 & DNK & 1.81 & LTU & 1.48 & FIN & 1.56 \\
\hline 10 & $\mathrm{CHN}$ & 1.49 & KOR & 1.28 & HRV & 2.46 & NLD & 1.81 & RUS & 1.44 & ITA & 1.56 \\
\hline $\mathrm{CHN}$ & - & - & - & - & 14 & 2.02 & 23 & 1.07 & 20 & 1.01 & 14 & 1.28 \\
\hline \multirow{2}{*}{$\begin{array}{l}\text { Industry } \\
\text { ranking }\end{array}$} & \multicolumn{2}{|c|}{ C10 } & \multicolumn{2}{|c|}{$\mathrm{C} 13$} & \multicolumn{2}{|c|}{ C14 } & C15 & \multicolumn{3}{|c|}{ C11 } & \multicolumn{2}{|c|}{$\mathrm{C} 12$} \\
\hline & Nation & $R C A$ & Nation & $R C A$ & Nation & $R C A$ & Nation & $R C A$ & Nation & $R C A$ & Nation & $R C A$ \\
\hline 1 & RUS & 4.61 & $\mathrm{CZE}$ & 3 & TUR & 2.5 & JPN & 2.35 & KOR & 2.32 & IRL & 7.9 \\
\hline 2 & GRC & 4.14 & SVK & 2.84 & $\mathrm{CZE}$ & 2.4 & KOR & 1.92 & BEL & 1.68 & $\mathrm{CHE}$ & 7.53 \\
\hline 3 & IDN & 3.08 & SVN & 2.37 & PRT & 2.31 & RUS & 1.91 & TWN & 1.54 & DNK & 5.66 \\
\hline 4 & IND & 2.52 & HUN & 2.15 & SVN & 2 & $\mathrm{CAN}$ & 1.8 & USA & 1.43 & SVN & 5.18 \\
\hline 5 & LTU & 2.47 & JPN & 2.04 & HRV & 1.93 & TUR & 1.72 & $\mathrm{DEU}$ & 1.35 & BEL & 2.48 \\
\hline 6 & KOR & 1.9 & POL & 1.99 & $\mathrm{CHN}$ & 1.87 & $\mathrm{CHN}$ & 1.51 & IND & 1.29 & HUN & 2.32 \\
\hline 7 & TWN & 1.81 & IDN & 1.66 & ITA & 1.87 & GRC & 1.51 & FRA & 1.21 & FRA & 1.95 \\
\hline 8 & JPN & 1.63 & PRT & 1.66 & LVA & 1.84 & MEX & 1.51 & IDN & 1.19 & HRV & 1.75 \\
\hline 9 & USA & 1.51 & DEU & 1.61 & BGR & 1.77 & TWN & 1.35 & NLD & 1.18 & ITA & 1.66 \\
\hline
\end{tabular}




\begin{tabular}{|c|c|c|c|c|c|c|c|c|c|c|c|c|}
\hline 10 & HUN & 1.22 & LTU & 1.57 & POL & 1.75 & AUT & 1.34 & $\mathrm{CHN}$ & 1.15 & DEU & 1.64 \\
\hline $\mathrm{CHN}$ & 16 & 0.98 & 16 & 1.3 & - & - & - & - & $\longrightarrow$ & - & 31 & 0.32 \\
\hline \multirow{2}{*}{$\begin{array}{c}\text { Industry } \\
\text { ranking }\end{array}$} & \multicolumn{2}{|c|}{ C16 } & \multicolumn{2}{|c|}{$\mathrm{C} 17$} & \multicolumn{2}{|c|}{ C18 } & C19 & \multicolumn{3}{|c|}{$\mathrm{C20}$} & \multicolumn{2}{|c|}{ C21 } \\
\hline & Nation & $R C A$ & Nation & $R C A$ & Nation & $R C A$ & Nation & $R C A$ & Nation & $R C A$ & Nation & $R C A$ \\
\hline 1 & SVN & 3.19 & TWN & 6.98 & SVN & 2.57 & DEU & 2.45 & CZE & 3.73 & KOR & 2.99 \\
\hline 2 & SVK & 3.14 & KOR & 3.33 & CZE & 2.56 & ITA & 2.39 & HUN & 3.7 & FRA & 2.39 \\
\hline 3 & CZE & 2.67 & JPN & 2.05 & DEU & 2.2 & FIN & 2.14 & JPN & 3.47 & USA & 2.36 \\
\hline 4 & ITA & 2.62 & $\mathrm{CHN}$ & 1.84 & ROU & 2.11 & AUT & 2 & SVK & 3.32 & GBR & 1.75 \\
\hline 5 & AUT & 2.12 & $\mathrm{CHE}$ & 1.52 & AUT & 2.09 & HUN & 1.79 & MEX & 3.22 & JPN & 1.5 \\
\hline 6 & HRV & 1.93 & USA & 1.16 & KOR & 1.96 & CZE & 1.63 & DEU & 3.14 & CAN & 1.47 \\
\hline 7 & POL & 1.89 & SWE & 1.14 & $\mathrm{CHN}$ & 1.8 & JPN & 1.56 & KOR & 1.93 & IND & 1.11 \\
\hline 8 & DEU & 1.83 & FIN & 1.02 & JPN & 1.8 & SWE & 1.4 & SVN & 1.59 & ESP & 1.1 \\
\hline 9 & KOR & 1.76 & HUN & 0.99 & FIN & 1.7 & KOR & 1.29 & ESP & 1.39 & DEU & 1.07 \\
\hline 10 & EST & 1.74 & MEX & 0.98 & MEX & 1.61 & TUR & 1.25 & SWE & 1.32 & MEX & 0.89 \\
\hline $\mathrm{CHN}$ & 27 & 0.91 & - & - & - & 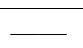 & 12 & 1.15 & 24 & 0.55 & 16 & 0.69 \\
\hline
\end{tabular}

entered are listed in the last line with specific rankings and RCA_GVC values.

\section{CONCLUSION}

Against the background of global production network, the division of labor and the ability of value creation are the important factors to determine the international competitiveness of the manufacturing sector. Therefore, there are great limitations in using the traditional RCA index to represent the international competitiveness of the industry. Based on the RCA_GVC index designed by Wang Zhi et al. (2015) from the perspective of global value chain, and using the latest version of the world input-output database, this paper estimates the international competitiveness of 18 manufacturing sectors in 44 economies in 20002014. On this basis, it analyzes the level characteristics, evolution trend and international status of the international competitiveness of China's manufacturing sector.

The results show that: firstly, the international competitiveness of China's manufacturing sector is quite different, and labor-intensive sectors show strong international competitiveness, especially in textile and clothing manufacturing; in addition, four capitalintensive sectors and two knowledge and technologyintensive sectors also show strong international competitiveness. As a whole, the international competitiveness of capital-intensive sectors is developing and expanding, while the international competitiveness of knowledge and technology-intensive sectors are still under cultivation, which is closely related to the current factor endowment structure and its changing trend in China. Secondly, the evolution trend of the international competitiveness of all sectors of manufacturing industry is seriously divided. The international competitiveness of knowledge-intensive sectors mostly shows a growth trend, while that of labor-intensive and capital-intensive sectors shows a downward trend. In addition, several sectors with poor international competitiveness fluctuate greatly when encountering external shocks, and even change the development direction. For example, American Financial Crisis has affected the development path of international competitiveness of many industries in China, which are generally dependent on the intermediate supply and consumer market of the US. Third, in the sample space, China has 7 industries ranking the top 10 and 14 industries ranking the top 20 . As a whole, the international competitiveness of China's manufacturing industry is in the middle and upper reaches, but there are also some knowledge and technology-intensive industries and capital-intensive industries whose international status is not ideal, which have greater room for improvement.

The above conclusions are of great significance to re understand the international competitiveness of China's manufacturing industry. First, although China has entered the global value chain with labor-intensive manufacturing industry, it has established a strong international competitiveness, which is not in the "lowend lock-in" state. In the short term, labor-intensive manufacturing industry is still the main pillar for China's manufacturing industry to participate in global competition. Against the background of the introduction of labor contract law, the increase of labor cost and the increase of environmental protection cost of enterprises, it is really not easy to achieve such excellent results. Therefore, China should provide more convenience and support for the development of laborintensive industries in terms of providing financial support, alleviating the burden on enterprises, providing employment services, etc. Secondly, China's factor endowment structure has undergone gratifying changes. 
Capital-intensive manufacturing industry has gradually grown into an industrial sector with international competitiveness, which has pointed out the path for the transformation and upgrading of China's manufacturing industry, and also put forward higher requirements for the tilt of national fiscal policy, the adjustment of monetary policy, the perfection of financial market and the construction of open market system. Specifically, China should make more reforms in reducing the cost of enterprise taxes and fees, improving the efficiency of administrative services, reforming the formation mechanism of interest rate marketization, cultivating multi-level and multi-channel capital market, and encouraging the construction of open economic system such as "going out" and "bringing in". Third, the knowledge and technology-intensive industry, except for the computer and optoelectronic industry, is generally not competitive and has a large gap with advanced economies. This is closely related to the overall development stage and factor endowment characteristics of the country. As the industry with the highest added value, it must become the development direction of China's manufacturing industry in the future, so it is necessary to support the cultivation of enterprises in this industry. On the one hand, it is required to strengthen investment in education and scientific research, encourage the public and enterprises to engage in innovative labor, especially the research and development of key core technologies, strengthen the construction and enforcement of laws and regulations on intellectual property, protect the interests of the property owners of research and development achievements, and make the innovation-driven strategy truly implemented. On the other hand, it is necessary to encourages enterprises to participate in international competition and cooperation, and accelerate the formation of high-tech chain and value chain through technology introduction, talent introduction, cooperative development, merger and reorganization, etc.

\section{References}

[1] Hausmann R, Hwang J, Rodrik D. What You Export Matters [J]. Journal of Economic Growth, 2007, (1):1-25.

[2] Lemoine F, Nal-Kesenci D. Rise of China and India in International Trade: From Textiles to New Technology [J]. China \& World Economy, 2008, (5):16-34.

[3] Schott P K. The relative sophistication of Chinese exports [J]. Economic Policy, 2008, 23(53):5-49.

[4] Fuest C. The Relative Sophistication of Chinese Exports: Comment on Peter Schott [J]. Economic Policy, 2008, (53):549.

[5] Johnson R C, Noguera G. Accounting for Intermediates: Production Sharing and Trade in Value Added [J]. Journal of International Economics, 2012, (2):224-236.

[6] Theodore, Moran. Foreign Manufacturing Multinationals and the Transformation of the Chinese Economy [J]. China's Foreign Trade, 2011, (15):42-45.
[7] Krugman P. Competitiveness: A Dangerous Obs ession [J]. Foreign Affairs, 1994, (2):28-44.

[8] Hu Zhaoling, Song Jia. The Specialization Status of China: An Analysis Based on Export Price [J]. Journal of International Trade, 2013, (3): 15-25. (in Chinese)

[9] Xu Meina, Shen Yuliang. Intra-Product Specialization, Sino-US Trade Surplus and Trade Interests: From the Micro Perspective of NB Enterprises [J]. World Economy Study, 2011, (4): 43-48. (in Chinese)

[10] Balassa B. Trade Liberalization and "Revealed" Comparative Advantage [J]. Manchester School, 1965, (2):99-123.

[11] Lall, Sanjaya, John Weiss, and Jinkang Zhang. The "Sophistication" of Exports: A New Trade Measure [J]. World Development, 2006,(2): 222-237.

[12] Jin Bei, Li Pengfei, Liao Jianhui. The Current Situation and Trend of International Competitiveness of Industries in China An Analysis Based on Export Commodities [J]. China Industrial Economy, 2013, (5): 5-17. (in Chinese)

[13] Fu Jingyan, Li Lisha. A Case Study on the Environmental Regulation, the Factor Endowment and the International Competitiveness in Industries [J]. Management World, 2010, (10): 87-98. (in Chinese)

[14] Ge Ming, Zhao Suping. Logical Relation and Empirical Comparison between Trade of Gross Value, Value-Added in Trade \& Trade in Value-Added [J]. Wuhan University Journal (Philosophy and Social Sciences Edition), 2017, (2): 61-72. (in Chinese)

[15] Hummels D, Ishii J, Yi K M. The Nature and Growth of Vertical Specialization in World Trade [J]. Social Science Electronic Publishing, 1999, (1):75-96.

[16] Daudin G, Schweisguth D. Who Produces for Whom in the World Economy? [M]// Canadian Journal of Economics/Revue Canadienne D'économique. 2011:1403-1437.

[17] Robert Koopman, William Powers, Zhi Wang, et al. Give Credit Where Credit is Due: Tracing Value Added in Global Production Chains [J]. NBER Working Papers, 2010.

[18] Ma H, Wang Z, Zhu K. Domestic content in China's exports and its distribution by firm ownership [J]. Journal of Comparative Economics, 2015, 43(1):3-18.

[19] Stehrer,R. Trade in Value Added and the Value Added in Trade. WIOD Working Paper, 2012, 81.

[20] Timmer, Marcel P., et al. Slicing Up Global Value Chains [J]. Journal of Economic Perspectives, 2014, (2): 99-118.

[21] Li Xin, Xu Dianqing. Reassessing China's Foreign Trade Degree of Dependence and Imbalance: Value-Added Trade in the Global Link of Production [J]. Social Sciences in China 2013, (1): 29-55. (in Chinese)

[22] Wang, Zhi, Shang-Jin Wei, and Kunfu Zhu. Quantifying international production sharing at the bilateral and sector levels. No. w19677. National Bureau of Economic Research, 2013.

[23] Wang Zhi, Wei Shangin, Zhu Kunfu. Gross Trade Accounting Method: Official Trade Statistics and Measurement of the Global Value Chain [J]. Social Sciences in China, 2015, (9): 108-127. (in Chinese)

[24] Zeng Xun. Research on the Current Account's Sustainability and Industrial Competitiveness of China and U.S. - Based on the Perspective of Trade in Value Added Perspective [J]. Modern Economic Science, 2017, 39 (6): 57-66. (in Chinese)

[25] Dai Xiang. International Competitiveness of China's Manufacturing Industry -- A Measurement Based on Trade in Value Added [J]. China Industrial Economy, 2015, (1): 78-88. (in Chinese)

[26] Yuan Honglin, Xu Yue. Recalculation of China's Manufacturing Export Competitiveness from the Perspective of Value Added 
Trade [J]. Contemporary Finance \& Economics, 2017, (12): 98107. (in Chinese)

[27] Koopman,R., Wang,Z.\&Wei,S.J.. Tracing Value-Added and Double Counting in Gross Exports [J]. American Economic Review, 2014, (2): 459-494.

[28] Ge Ming, Lin Ling. The Study of China's Foreign Trade Imbalance: A Value-Added Approach [J]. International Economics and Trade Research, 2016, (2): 20-33. (in Chinese) 